\title{
Bioacoustics and systematics of the Poecilimon heroicus-group (Orthoptera: Phaneropteridae: Barbitistinae)
}

\author{
KLAus-Gerhard HELLER ${ }^{1}$, Olga S. KORSUNOVSKAYA ${ }^{2}$, HASAN SEVGILI ${ }^{3}$ and Roustem D. ZHANTIEV ${ }^{2}$ \\ ${ }^{1}$ Grillenstieg 18, 39120 Magdeburg, Germany; e-mail: Heller.volleth@t-online.de \\ ${ }^{2}$ Department of Entomology, Moscow Lomonosov State University, Vorobiovy Gory, Moscow 119992, Russia; \\ e-mails: korsuno@aport.ru; zhantiev@mail.ru \\ ${ }^{3}$ Harran Üniversitesi, Fen-Edebiyat Fakültesi, Biyoloji Bölümü, Osmanbey Kampüsü, Sanliurfa, Turkey; \\ e-mail: hsevgili@harran.edu.tr
}

Key words. Orthoptera, Poecilimon, morphology, systematics, bioacoustics, Tettigonioidea, bush-crickets, communication system, evolution

\begin{abstract}
The species of the Poecilimon heroicus-group occur around the Caucasus (from north-eastern Turkey to south-eastern Ukraine). We describe the diagnostic morphological characters of all these species and the male calling song of three of the four species. Based on this data the following phylogenetic relationship is derived ( $P$. tschorochensis $(P$. tricuspis $(P$. heroicus, $P$. bifenestratus))). Within the genus Poecilimon, the species can be recognised by a relatively wide pronotum and large tegmina. In one species, Poecilimon tschorochensis Adelung, 1907 (type species of the monotypic genus Artvinia Karabag, 1962, syn. n.; P. rammei Miram, 1938, syn. n.), the tegmina are very large and the song has unusually low spectral components. This species produced disyllabic echemes at intervals of about $10 \mathrm{~s}$. In two other species of the group, P. heroicus and P. bifenestratus, the calling song of males consists of an uninterrupted dense sequence of long syllables (syllable duration around $0.5 \mathrm{~s}$; ca. 1 syllable/s at $20^{\circ} \mathrm{C}$ ). In these species the auditory spiracles are reduced in size in both sexes, and the females have extremely small tegmina and are unable to respond to the male song acoustically, which would be typical for Phaneropteridae. The change in communication from acoustically responding to mute females has not been previously documented within a group of closely related species.
\end{abstract}

\section{INTRODUCTION}

The tettigonioid family Phaneropteridae (often considered as subfamily Phaneropterinae) contains about 2200 species (OSF2), nearly one third of all known bushcrickets. Like all tettigonioids, Phaneropteridae communicate acoustically to find a mate. But unlike most other bush-crickets, where the mute female approaches the singing male, in Phaneropteridae typically the female responds acoustically to male song. This may be one of the reasons why some phaneropterid species have very complicated song patterns (e.g. Walker et al., 2003). Only in some species of the genus Poecilimon have the females lost their ability to respond acoustically, and this is associated with interesting changes in morphology and behaviour of males and females (Heller \& Helversen, 1993; Stumpner \& Heller, 1992).

While most phaneropterid species are long-winged, Poecilimon belongs to a species-rich group of shortwinged species, the subfamily Barbitistinae (or tribe Barbitistini). About 150 described forms of Poecilimon occur in Europe and West Asia, with their centre of distribution north of the Eastern Mediterranean. The phylogenetic relationships within Poecilimon are still unresolved, but probably the ability to respond acoustically was lost several times independently (Heller, 1990).

Below the species of the Poecilimon heroicus-group are revised and their calling songs and evolutionary relationships described. Already in the first revision of Poecilimon Ramme (1933) grouped these species together.
Evidence is presented that the loss of the acoustical females occurred within this group, in contrast to previous studies of other species groups of Poecilimon, which are homogeneous in this respect (Heller \& Lehmann, 2004; Heller \& Sevgili, 2005; Lehmann, 1998).

The group is also interesting from another aspect. Bush-crickets produce their calling songs by stridulation using their fore wings. In Poecilimon and other shortwinged members of the Barbitistinae this seems to be the only function of the tegmina, which therefore should be modified to optimise sound production. Despite being their only function, the size of the tegmina varies greatly. In some species they are of moderate size, in others small to very small and completely concealed under the pronotum (e.g. Heller, 2004). In P. tschorochensis (including $P$. rammei), however, they are huge, covering according to the description - nearly the whole abdomen. Details of the unusual song of this species are presented.

\section{MATERIAL AND METHODS}

We studied specimens preserved in the following collections: $\mathrm{CH}$ (followed by the specimen code) - Collectio Heller; HUZOM - Hacettepe Üniversitesi Zooloji Müzesi, Ankara, Turkey; MSPU - Moscow State Pedagogical University, Moscow, Russia; ZIN - Zoological Institute, Russian Academy of Sciences, St. Petersburg, Russia; ZMHB - Museum für Naturkunde der Humbolt-Universität, Berlin, Germany; ZMUM - Department of Entomology, Moscow University, Moscow, Russia. Other material is deposited in ZMUH - Zoologisches Museum Universität Hamburg, Hamburg, Germany. 


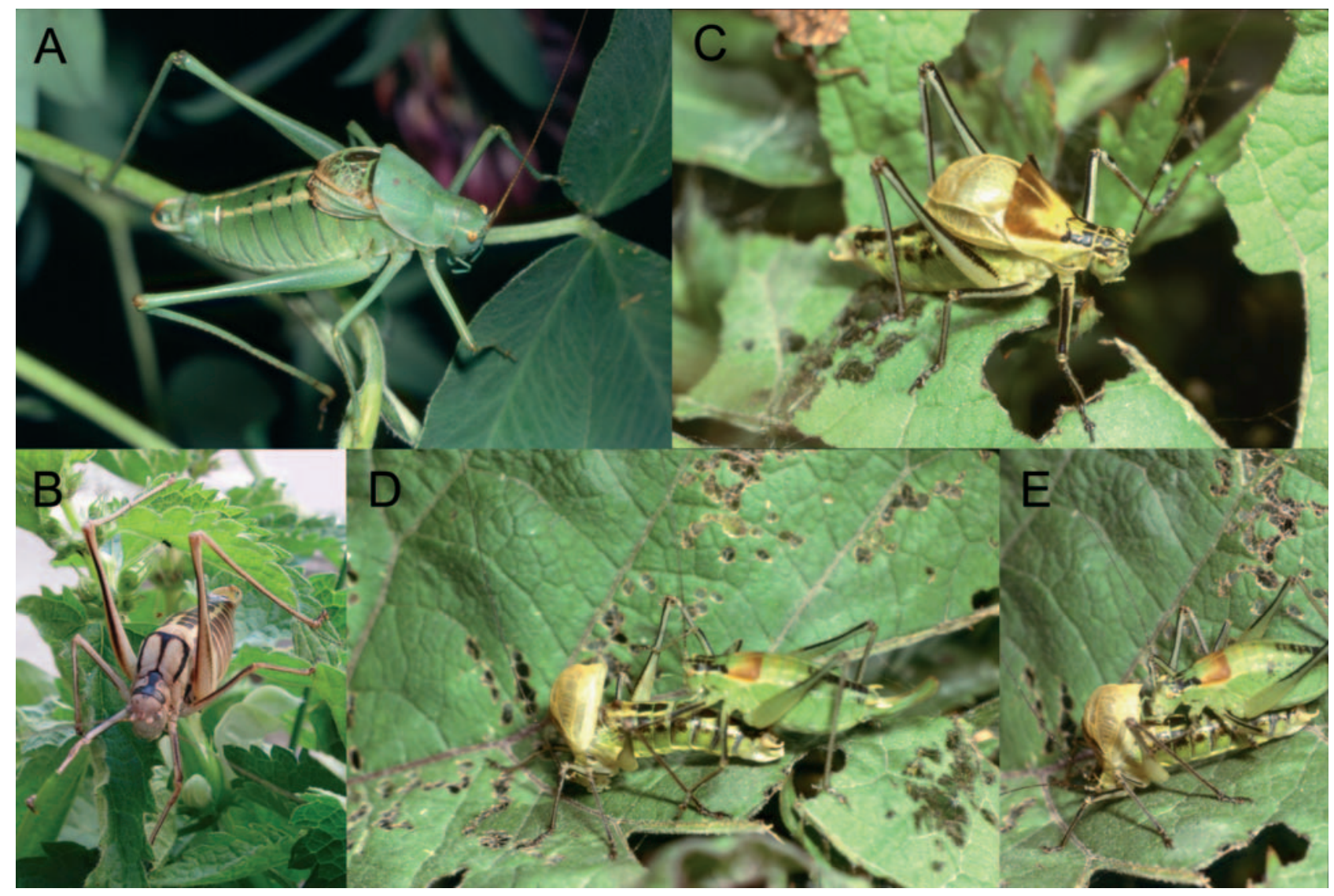

Fig. 1. A - Poecilimon heroicus, male (Lugansk, Ukraine); B - P. bifenestratus (Krasnodar area, near Novorossijsk), C - P. tschorochensis, male; D, E - P. tschorochensis, male and female during courtship (C-E Yalnizcam pass, Turkey).

Morphological structures were examined and measured using an Olympus stereomicroscope. For sound recording in the field an Uher tape recorder 4200 IC or a Sony WM-D3 cassette tape recorder with a Uher M645 microphone was used (frequency response flat up to $20 \mathrm{kHz}$ resp. $15 \mathrm{kHz}$ ), in the laboratory a Racal store 4 D tape recorder with Brüel \& Kjaer 4133 and 4135 microphones (frequency response flat up to 40 resp. $70 \mathrm{kHz}$ ), or a modified tape recorder "Yupiter-202 Stereo" with linear characteristic in the range $0.063-70 \mathrm{kHz}$, or a PC with A-D converter card L-305 (L-card) $(0-300 \mathrm{kHz})$ and 00017 RFT microphones (frequency response flat up to $70 \mathrm{kHz}$ ) was used. Songs of some specimens of $P$. tschorochensis were recorded in the laboratory using a Sony WM-GX688 Walkman and a stereo microphone $(50 \mathrm{~Hz}$ to $18 \mathrm{kHz})$ at $29^{\circ} \mathrm{C}$. After digitising the songs on a PC or an Apple computer, oscillograms (after filtering) and sound analysis were made using a PC and the programs Turbolab, Amadeus (Apple) and CoolEdit. Time measurements are given as mean \pm standard deviation if not otherwise stated. For the spectral measurements a $10 \mathrm{~ms}$ portion (sampling rate $160 \mathrm{kHz}$ ) of the respective song was analysed and in the figures the mean of 524 point FFT frames was presented. Wing movements were registered by an opto-electronic device (Helversen \& Elsner, 1977; modified as in Heller, 1988). Due to the heating effect of the registration lamps, only a lower limit for the body temperature can be given (see Heller, 1988). The actual body temperature may be up to 4 degrees higher than the ambient air temperature (measurements marked by " $>$ "). Some sound data for $P$. heroicus are available at the taxonomic database SysTax.

The stridulatory files were studied using scanning electron microscopes S-405 A (Hitachi) and JSM 840A (JEOL).
The map was produced using the program Versamap (http://www.versamap.com/)

\section{Bioacoustic terminology}

Calling song: spontaneous song produced by an isolated male. Syllable: the sound produced by one opening-closing movement cycle of the tegmina. Opening/closing hemisyllable: the sound produced by one opening or closing movement of the tegmina. Syllable duration: time from beginning of the first to end of the last impulse. Syllable interval: time from end of last impulse to beginning of first impulse of the next syllable. Syllable period: syllable duration + syllable interval. Impulse: a simple, undivided, transient train of sound waves generated by the impact of one tooth of the stridulatory file. Pulse: a long train of sound waves, resulting from the fusion of several impulses. Afterclick: an isolated impulse after the end of the main impulse group.

\section{RESULTS}

\section{Genus Poecilimon Fischer, 1853}

Type species: Poecilimon jonicus (Feiber, 1835) by subsequent designation (Kirby 1906: 375, as Poecilemon).

Artvinia Karabag, 1962, syn. n. Type species: Poecilimon tschorochensis Adelung, 1907.

In 1962, Karabag established the genus Artvinia for $P$. tschorochensis. This species has certainly some unique characters, but is without doubt quite closely related to the species of the Poecilimon heroicus-group (see above) and should therefore be considered as an aberrant member of this genus. It is the only Poecilimon species 

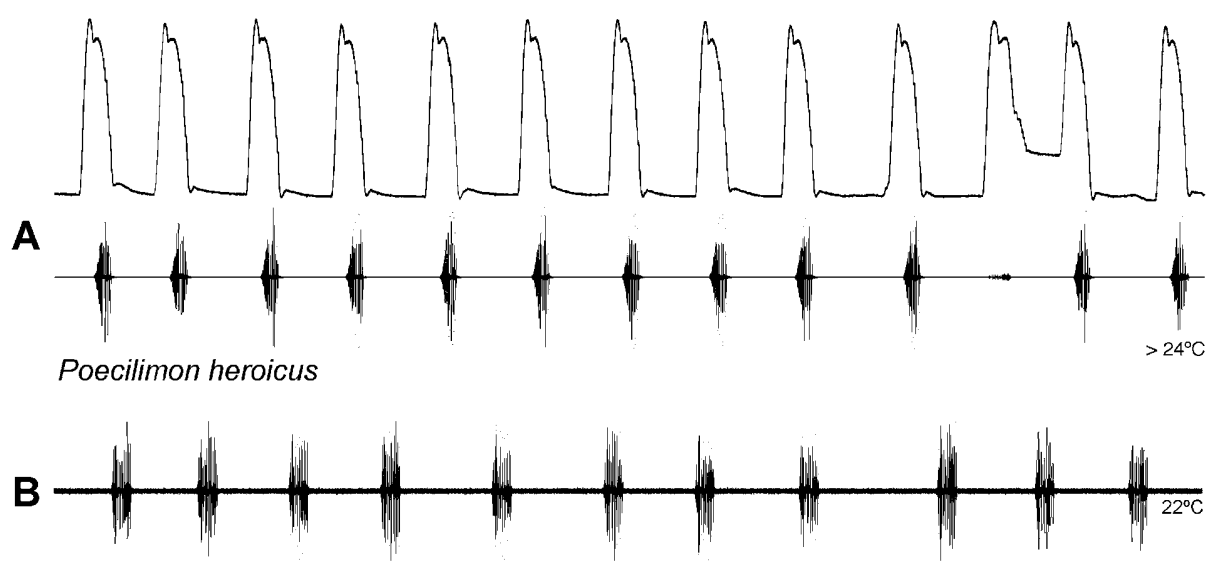

Poecilimon bifenestratus

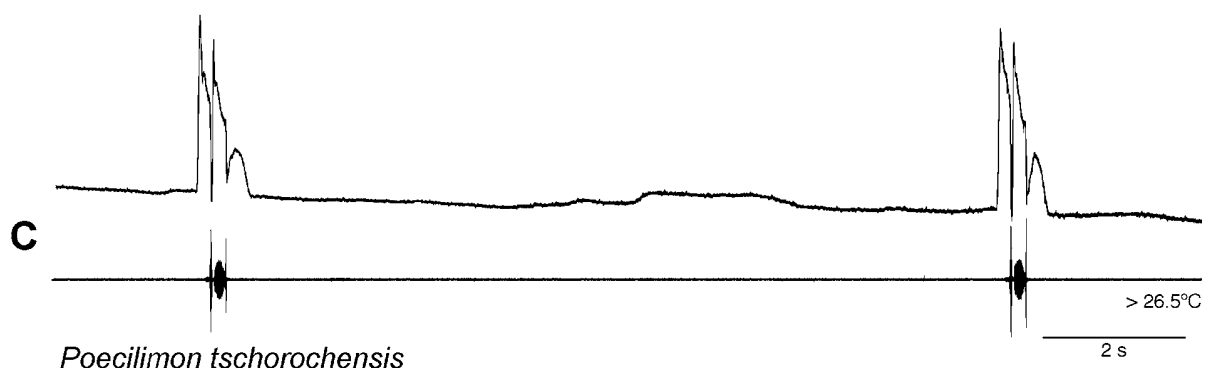

Fig. 2. Oscillograms of the stridulatory movements and song [synchronous registration of left tegmen movement (upward deflection represents opening, downward closing) and sound] of A - Poecilimon heroicus, B - P. bifenestratus (song only) and C $-P$. tschorochensis.

with huge, balloon-like tegmina (Fig. 1). In the structure of the pronotum, another character used by Karabag (1962) to define Artvinia, it comes close to P. heroicus and allied species. Large dorsal glands on the first or second tergite have evolved independently in several species of Poecilimon (Heller \& Lehmann, 2004). In $P$. tschorochensis a large, gland-like structure covered with hairs is situated on the second tergite and smaller ones on the first tergite and even metanotum. Small glands, indicated by an elevation of the central part of the posterior border, can also be found on the first tergite of $P$. heroicus. They occur, however, also in other species like $P$. affinis (own observations) and are probably often overlooked because they are covered by the tegmina. The relationship between $P$. tschorochensis and the genus Phonochorion, another group of species with dorsal glands, is unclear. Phonochorion is also endemic to Georgia and north-eastern Anatolia, but is very different from P. tschorochensis (and other Poecilimon) in morphology (compare figures in Karabag 1956 and Karabag 1962) and song (Phonochorion: continuous song (Heller 1990), P. tschorochensis: isolated pairs of syllables, see below).

\section{Characteristics of the Poecilimon heroicus-group}

From a direct comparison of most European and Anatolian Poecilimon species (e.g., Heller, 1984; Sevgili, 2001; Heller \& Lehmann, 2004; Heller et al., 2005; unpubl. studies) and the literature, it became evident that this group of species of this genus can be separated and recognised by the following characters:
(1) pronotum broader posteriorly (pronotum at its widest more than 1.4 times width of the head; Fig. 1)

(2) body size relatively large to medium compared to other Poecilimon species

(3) hind femora with ventral spines

(4) song consisting of long syllables (ca. $0.3-0.6 \mathrm{~s}$ at $18^{\circ} \mathrm{C}$; Figs 2-3)

Members of the Poecilimon heroicus-group are recognised by a combination of characters. But by far the most characteristic feature is the posteriorly widened pronotum (1), which can be considered as a unique autapomorphic character of the group. Some or even all of the other characters are possibly plesiomorphic. Body size (2) is a character difficult to assign as either an apomorphic or plesiomorphic state. The possession of spines on the ventral edges of the hind femora (3) is also difficult to evaluate. The spines may be helpful to free entangled hind legs in dense vegetation (e.g. Cuscuta: personal observations $\mathrm{KGH}$ ) and therefore more important for species living near the ground than for bush or tree inhabiting forms. It is certainly a plesiomorphic character for Orthoptera, but the situation for the Barbitistinae is unclear. A slow stridulatory movement (4) was assumed to be a plesiomorphic character of the subfamily Barbitistinae by Heller (1990).

Within the Aegaeid genus Poecilimon (Ciplak, 2004) the $P$. heroicus group may be related to other groups with large body size like the $P$. ornatus/affinis and $P$. sanctipauli groups (Heller \& Sevgili, 2005). Most members of these three groups share a calling song consisting of long 

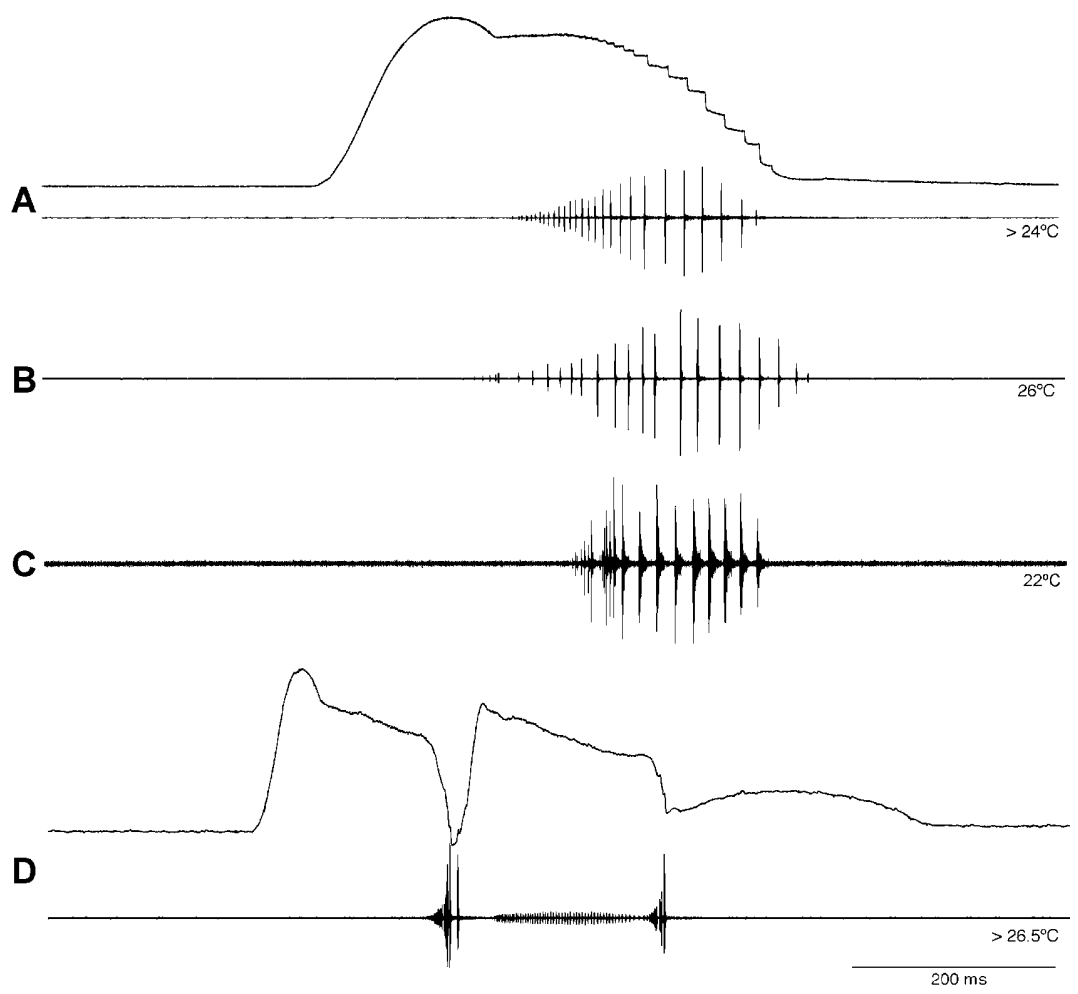

Fig. 3. Oscillograms of the stridulatory movements and song [synchronous registration of left tegmen movement (upward deflection represents opening, downward closing) and sound] of A - Poecilimon heroicus, B - P. cf. heroicus (song only), $\mathrm{C}-P$. bifenestratus (song only), D - P. tschorochensis.

syllables with numerous impulses, hind femora with ventral spinules and a wide fastigium (narrow in P. tschorochensis and $P$. tricuspis of the $P$. heroicus-group). The $P$. heroicus-group can be considered as the Caucasian branch within this relationship, with the $P$. ornatus/ affinis-group occurring in the Balkans and the $P$. sanctipauli-group in western Anatolia.

Distribution. Caucasus and surrounding regions (from southern Ukraine (Donets Hills) to north eastern Turkey; see Fig. 11).

\section{Description of species}

(see Table 1 for a review of characters)

\section{Poecilimon heroicus Stshelkanovtzev, 1911}

Type: Ukraine: SE, Provalskii stud farm on the Donets Hills (ZIN, lectotype male).

P. heroicus: Stshelkanovtzev, 1911: 175, Fig.14 (description); Uvarov, 1915: 88 (distribution); Stshelkanovtzev, 1921: 135 (distribution); Uvarov, 1928: 77-78 (key) Mushinsky, 1930 65, 68-69 (agricultural pest, biology); Bey-Bienko, 1930: 55 (distribution), 1932: 5 (biology), 1933: 318 (distribution); Ramme, 1933: 506, 509 (arrangement), 511 (checklist), 518-519 (description); Tarbinsky, 1948: 84 (key); Ramme, 1951: 416 (distribution); Bey-Bienko, 1954: 255 (key), 281-3 (description); Harz, 1969: 99, 113 (key), 141 (description); Mistshenko, 1972: 22 (agricultural pest); WarchalowskaSliwa et al., 1995: 28 (karyotype); Warchalowska-Sliwa, 1998: 157 (karyotype); Otte, 1997: 123 (catalogue); Heller et al., 1998: 29 (check-list); Naskrecki \& Otte, 1999: (catalogue); Zhantiev \& Korsunovskaya, 2005: 107, 109 (song). Databanks: SysTax, OSF2, FaEu.
Poecilimon affinis (Frivaldszky, 1867): Pylnov, 1909: 20 (description), Stshelkanovtzev, 1910: 49 (distribution); Medvedev, 1950: 91, 97, 105 (biology, distribution).

Remarks. The description is based on a series of syntypes (13 males, 4 females), which were deposited in the Zoological Museum Moscow. However, today no specimen of this series is found there. Bey-Bienko (1954) apparently examined parts of the type series and mentions one male as type and two other (one male, one female) as paratypes, all of them now deposited in ZIN and labelled as type and paratypes. We accept the selection of Bey-Bienko (1954: 283) and designate these specimens as lectotype and paralectotypes.

The location of the other syntypes is unknown. In any case, they are not, as mentioned for the holotype (!) by Otte (1997), Naskrecki \& Otte (1999) and OSF, in Instytut of Zoologii, Polska Akademia Nauk, Warsaw, Poland and have never been there (A. Liana, pers. comm.).

Material examined. Russian Federation: Daghestan: 2 $\widehat{0}$, Kizljar, Vysha-Talovka 25.vi.1930, leg. Bey-Bienko (ZMHB); Northern Caucasus, Krasnodar area: 19 , between Dakhovskaya and Khamyshki, south of Maikop, 12.viii.1937, leg. Dyakonov (ZMHB); Northern Caucasus, Tersky ridge near Grozny, vi.1986. leg. N. Sorokin; Ukraine: 60ิ, 3 ㅇ, Lugansk, Lugansk reserve, 12.vi.1996, leg. A. Benediktov (CH3310, CH4632, ZMUM).

Previous records. Russian Federation: Kabardino-Balkar (Warchalowska-Sliwa et al., 1995); for other records see list in Bey-Bienko, 1954.

Bioacoustics. The calling song consists of long, homogenous sequences of syllables (Fig. 2). These sequences last many seconds or even minutes (longest recorded sequence $85 \mathrm{~s}$ ). The mean duration of a syllable 
TABLE 1. Diagnostic characters of species of Poecilimon heroicus-group.

\begin{tabular}{|c|c|c|c|c|}
\hline Characters / Species & tricuspis & heroicus & bifenestratus & tschorochensis \\
\hline Fastigium of male narrower than scapus & yes & no & no & yes \\
\hline $\begin{array}{l}\text { Posterior part of male pronotum less than } \\
\text { twice as wide as anterior part }\end{array}$ & yes & yes & yes & no (very widened) \\
\hline Length of male tegmina (in $\mathrm{mm}$ ) & $\begin{array}{c}\text { 5-5.5 (whole tegmen) } \\
4-4.2 \text { (visible part) }\end{array}$ & $\begin{array}{l}\text { 8.6-10 (whole tegmen) } \\
4-7.5 \text { (visible part) }\end{array}$ & $\begin{array}{l}7.5-8.5 \text { (whole tegmen) } \\
3.8-5 \text { (visible part) }\end{array}$ & $8-9$ \\
\hline Tegmina of male strongly inflated & no & no & no & yes \\
\hline Tegmina of female contiguous dorsally & yes & no & no & yes \\
\hline $\begin{array}{l}\text { Cerci of male much thinner apically than } \\
\text { subapically }\end{array}$ & yes & no & no & no \\
\hline Cerci of male bears two spines apically & yes & yes & yes & no \\
\hline Cerci of male thickened apically & no & no & no & yes \\
\hline Ovipositor length (mm) & $13-14$ & $11.5-12.5$ & $16.5-18.5$ & $8-9$ \\
\hline Number of teeth on male stridulatory file & $?$ & $(62-) 79$ & 60 & \pm 146 \\
\hline Length of male hind femora (mm) & 18.6 & $18.5-23$ & $21-24$ & $14.5-16$ \\
\hline Length of female hind femora (mm) & $22-22.5$ & $20-22.5$ & $24-24.5$ & $13.5-16.5$ \\
\hline
\end{tabular}

was between about $400 \mathrm{~ms}(\mathrm{n}=6$ males from Ukraine; $\mathrm{T}$ $=18.5-22^{\circ} \mathrm{C}$ ) and $500 \mathrm{~ms}$ (male from Caucasus: $486 \pm 28$ ms, $\mathrm{n}=8$ syllables; $\mathrm{T}=22^{\circ} \mathrm{C}$ ), that of the interval between $600-900 \mathrm{~ms}\left(\mathrm{n}=12, \mathrm{~T}=22^{\circ} \mathrm{C}\right)$ and $1218 \pm 85$ $\mathrm{ms}\left(\mathrm{n}=10, \mathrm{~T}=18.5^{\circ} \mathrm{C}\right)$. The syllables are produced only during the closing movement of the tegmina (Fig. 3). The steps during the closing movement probably indicate the contact of the scraper with a single tooth of the stridulatory file resulting in a sound impulse (see also below). The syllables were composed of 20-38 impulses. The impulse period in the second half of the syllable varied between 8.7 and $15.2 \mathrm{~ms}$ (mean values of 2 males, $\mathrm{T}>$ $24^{\circ} \mathrm{C}$ ), increasing at lower temperatures (e.g. $23 \mathrm{~ms}, \mathrm{~T}=$ $18.5^{\circ} \mathrm{C} ; 25$ and $33 \mathrm{~ms}, \mathrm{~T}=22^{\circ} \mathrm{C} ; \mathrm{n}=8-10$ syllables/ male). The carrier frequencies of the song had the maximum at $12 \mathrm{kHz}$ (bandwidth $10 \mathrm{~dB}$ below peak: $10-17 \mathrm{kHz} ; \mathrm{n}=2$ males; Fig. 4).

From Fig. 2 it can be recognised that uniquely the male opened and closed the tegmina producing only a weak sound. Closer examination revealed that in this case, just before sound production - during the opening phase of the tegmina - a male of another Poecilimon species sitting nearby produced a quite loud but completely ultrasonic song. Obviously this noise disturbed the regular sound production and only a faint sound (about 34 impulses, duration $100 \mathrm{~ms}$, earlier in the closing movement than a regular syllable) was recorded. Interestingly, however, the steps during the late closing movement are still visible, although different in amplitude compared to a regular syllable. So in this case either the contact between scraper and teeth did not produce sound or the steps were produced by neuronal activation of another muscle than that responsible tegminal contact and sound amplitude.

The females do not respond acoustically and their tegmina are greatly reduced in size and do not overlap dorsally. In males and females the prothoracic spiracles are very small, comparable to those in Poecilimon thessalicus (veluchianus) (Stumpner \& Heller, 1992).

Pars stridens: The stridulatory file bears relatively few $(79 ; \mathrm{n}=1)$, widely spaced stridulatory teeth (Fig. 9).
One male, collected by M. Fyodorova in Northern Caucasus near Pjatigorsk, in July 1989, differs slightly in morphology and song from the Ukrainian animals. Zhantiev \& Korsunovskaya (2005) refer to it as Poecilimon sp. cf heroicus. Its song had distinctly larger syllable intervals (ca $5 \mathrm{~s}$ at $26^{\circ} \mathrm{C}$ ) than that of other specimens, but otherwise similar syllable structure (Fig. 3). The number of teeth on the stridulatory file is lower $(62 ; \mathrm{n}=1)$ than in $P$. heroicus (Fig. 9). It is necessary to obtain additional material to verify the taxonomic status of this form.

\section{Poecilimon bifenestratus Miram, 1929}

Type: Russian Federation: Krasnodar area, Western Caucasus, mountains near Gaiduk, $8 \mathrm{~km}$ northeast (NO in German) of Novorossijsk, 28.vi.1928, leg. Novickij (ZIN, holotype male; in addition in ZIN 10,19 paratypes).

P. bifenestratus: Miram, 1929: 115-117 (description); Ramme, 1933: 506, 509 (arrangement), 511 (checklist), 518-9 (description); Ramme, 1951: 416 (distribution); Bey-Bienko, 1954: 255 (key), 283-285 (description); Otte, 1997: 113 (catalogue); Heller et al., 1998: 28 (check-list); Naskrecki \& Otte, 1999: (catalogue); Stolyarov, 2005: 65 (behaviour, distribution). Databanks: SysTax, OSF2.

Remarks. In the description of $P$. bifenestratus Miram (1929) surprisingly did not compare it with or refer to P. heroicus. She explicitly stated that there is no species similar in size and morphology to P. bifenestratus in the Russian Federation and compared it only with Balkan and Aegean species. P. bifenestratus and $P$. heroicus, however, are very similar. The males can be recognised by small, but distinct differences in the shape of the cerci (Fig. 5), observed in all specimens examined. As described by Bey-Bienko (1954) the pronotum is slightly narrower in $P$. bifenestratus than in $P$. heroicus, but the tegmina are longer. Females of $P$. bifenestratus have distinctly longer hind legs and ovipositor than $P$. heroicus.

In addition, Bey-Bienko (1954) mentions differences in coloration. The colour, however, is very variable and we saw green specimens without the typical black "window" (bifenestratus) pattern on the pronotum, pinkish-yellow males and males with typical window and black colour on abdomen in the same habitat (OK; same observations by M. Stolyarov, pers. comm.). 

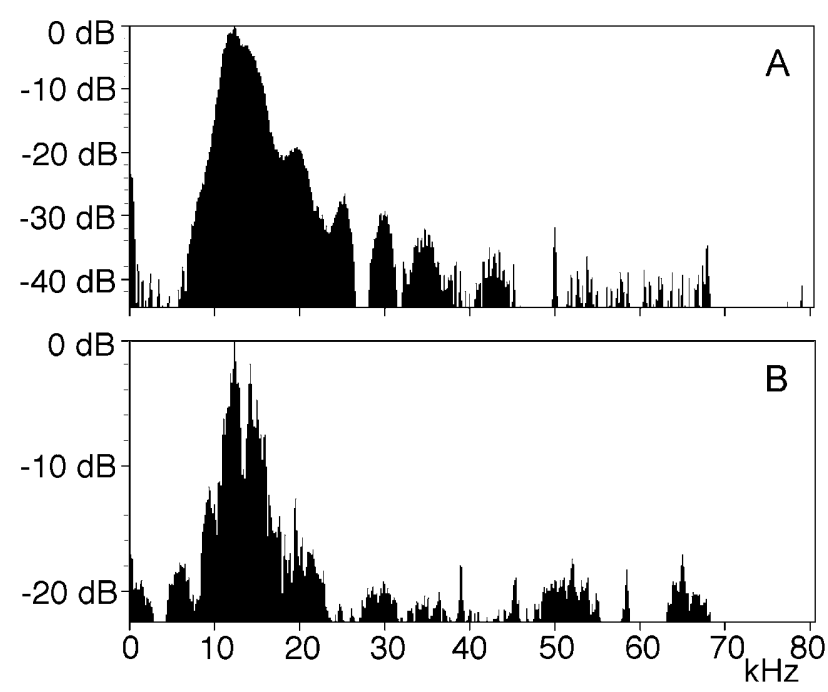

Fig. 4. Spectral composition of the calling song of Poecilimon heroicus (A) and P. bifenestratus (B).

Material examined. Russian Federation: Type and paratypes (ZIN), 10 paratype (ZMHB). 10 : Krasnodar area, near Novorossijsk, vil. N. Ozereevka, $400 \mathrm{~m}, 11 . v i .2001$, leg. Stolyarov $(\mathrm{ZIN})$; 1 \%: Krasnodar area, near Novorossijsk, vil. N. Ozereevka, about $350 \mathrm{~m}$, 14.vi.2001, leg. Stolyarov (ZIN); 1 đ̃: Krasnodar area, near Novorossijsk, Myskhako, vil. Fedotovka, 27.vi.1997, leg. Stolyarov (ZIN); 80, 1 i type locality, 23.-28.vi.2005, leg. O. Korsunovskaya (ZMUM).

Previous records. Russian Federation: Type locality Miram, 1929; Gelendzhik, Ramme, 1933 (this locality is cited by Stolyarov, 2005 erroneously as being published in Ramme, 1951); 4-7 km SW Novorossijsk, Stolyarov, 2005.

Bioacoustics. The calling song consists of long sequences of syllables (Fig. 2) as in P. heroicus. Males tend to chorus but do not regularly alternate with syllables. The mean duration of a syllable in three different males was $190 \pm 7.1,205 \pm 12.7$ and $260 \pm 7.2 \mathrm{~ms}$ $(\mathrm{n}=9,10$ and 14$)$ at $20-22^{\circ} \mathrm{C}$. Duration of intervals between syllables varied more significantly: in several animals the syllables were separated by intervals of about $1 \mathrm{~s}$ : e.g., one male at $20-22^{\circ} \mathrm{C}$ : $930-1657 \mathrm{~ms}$ (mean 1149 $\pm 193 \mathrm{~ms}, \mathrm{n}=13$ ), but another male sang with a higher syllable repetition rate (intervals $443-529 \mathrm{~ms}$, mean 483.3 $\pm 22.8 \mathrm{~ms}, \mathrm{n}=24)$ and mean duration of syllables of $220.2 \pm 13.2 \mathrm{~ms}(\mathrm{n}=25)$, a third male with a lower rate (intervals 1726-2623 ms, mean $1979 \pm 328 \mathrm{~ms}, \mathrm{n}=6$ ). Each syllable was composed of 3-9 initial impulses of low amplitude and 13-14 impulses with higher amplitude, increasing in the middle part of a syllable and decreasing in the final part (Fig. 3). The mean number of impulses per syllable varied in different males from 14.1 $\pm 1.2(\mathrm{n}=20$ syllables) to $21.1 \pm 0.7 \mathrm{~ms}(\mathrm{n}=7$ syllables; $\mathrm{T}=22^{\circ} \mathrm{C}$ ). Mean period of impulses in the second half of the syllable in three males varied between $17.5 \pm 2.8 \mathrm{~ms}$ and $23.8 \pm 2.9 \mathrm{~ms}\left(\mathrm{n}=8\right.$ syllables; $\left.\mathrm{T}=22^{\circ} \mathrm{C}\right)$. The carrier frequencies of the song had a maximum at $12-13 \mathrm{kHz}$ and additional high frequency peaks with lower amplitude (Fig. 4).
Pars stridens: The stridulatory file bears fewer teeth $(60 ; \mathrm{n}=1)$ than in P. heroicus (Fig. 9), but has a similar structure.

$P$. bifenestratus was collected in stony dry areas with grass, Salvia sp. and sparse bushes of Rosa sp. The males were found singing on the ground or on plants at an height of 40-50 cm. Males of Pholidoptera pustulipes (Fischer de Waldheim, 1846) and Poecilimon scythicus Shchelkanovtsev, 1911 were heard singing simultaneously with $P$. bifenestratus, even during the day.

\section{Poecilimon tricuspis Miram, 1926}

Type: Russian Federation, Northern Ossetia, Koban, 21.vi.1925, leg. Kiritshenko (ZIN, holotype male).

P. tricuspis: Miram, 1926: 276-277 (description); Ramme, 1933: 506, 509 (arrangement), 511 (check-list), 518-9 (description); Ramme, 1951: 416 (distribution); Bey-Bienko, 1954: 255 (key), 280-281 (description); Otte, 1997: 127 (catalogue); Heller et al., 1998: 30 (check-list); Chernyakhovsky, 1994: 106 (check-list); Naskrecki \& Otte, 1999: (catalogue); Stolyarov, 2005: 66 (distribution); Özbeg \& Aslan, 1996 (misidentification, see below). Databanks: OSF2.

Remarks. $P$. tricuspis is easy to separate from other members of the group by the shape of its cerci (compare Fig. 5 and 6).

In contrast to $P$. heroicus and $P$. bifenestratus, the tegmina overlap dorsally in the female so that she is able to produce sounds.

This species, which was known only from a few localities in Northern Ossetia, was recently recorded from north eastern Turkey (Özbeg \& Aslan, 1996). However, after examination of their material (preserved in Atatürk University-Erzurum, determined as $P$. tricuspis by E. Tazegül) and of new material from the same locality, it became obvious it was not $P$. tricuspis, but another Poecilimon species from the P. zonatus-group (HS).

Material examined. Russian Federation: Northern Ossetia: type series $(1 \hat{0}, 2 \hat{q})(\mathrm{ZIN}) ; 2 \hat{0}, 2 \hat{q}, \mathrm{~N}$. Ossetia, near village of Dargavs, Green pass, 1600 m, 5.viii.1993, leg. Stolyarov (ZIN); 10 , N. Ossetia, near village of Saniba, 1500-1600 m, 5.viii.1993, leg. Stolyarov (ZIN); 30 , 3 $q$, N. Ossetia, village of Zintsar, 8.viii.1982, leg. Chernyakhovsky (MSPU).

Previous records. Russian Federation: Northern Ossetia: type locality Miram 1926; Dargavs, Miram 1926 (as unidentified; identification by Bey-Bienko, 1954); Balta, Bey-Bienko, 1954; near village of Dargavs and near village of Saniba, Stolyarov, 2005.

Bioacoustics. Song unknown.

\section{Poecilimon tschorochensis Adelung, 1907}

Type: Turkey, Artvin district, "Passhöhe Jalanus-Tscham. Gegen 9000' Höhe" (= Yalnizcam pass), 1.vi.1898, leg. Deryugin (ZIN, holotype male).

Poecilimon rammei Miram, 1938, syn. n. Type: Turkey, "district Artvin, Batum region, 10.v.1910. leg. Nesterov" (ZIN, holotype male). Bey-Bienko (1954) adds information about the locality "Gurdzhany".

P. tschorochensis: Adelung, 1907: 66-68 (description), plate 1; Ramme, 1933: 506, 509 (arrangement), 511 (checklist), 518-9 (description); Ramme, 1951: 416 (distribution); BeyBienko, 1954: 256 (key), 286-287 (description, as P. tchorochensis [sic]); Karabag, 1958: 32 (faunistic catalogue); Karabag, 1962: 9-10 (description; transfer to genus Artvinia 

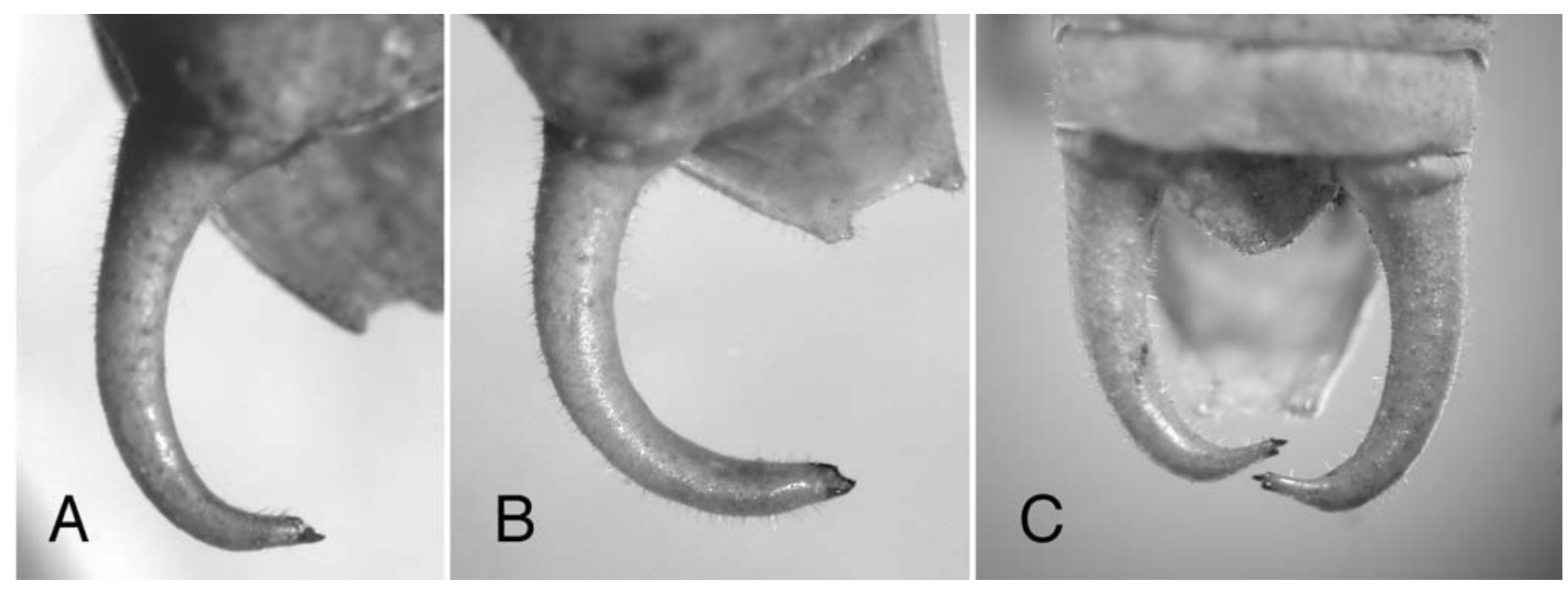

Fig. 5. Male cerci. A - Poecilimon heroicus (CH3310), B - P. bifenestratus (ZIN, leg. Stolyarov), C - P. tricuspis (holotype).

as its type species); Otte, 1997: 126 (catalogue, as P. tchorochensis [sic]); Naskrecki \& Otte, 1999: (catalogue, as P. tchochorensis [sic]). Databanks: SysTax, OSF2 (as $P$. tchochorensis [sic]).

P. rammei: Miram, 1938: 348-350, 362-363 (description); Ramme, 1951: 333-334 (description); Ramme, 1951: 416 (distribution); Bey-Bienko, 1954: 256 (key), 285-286 (description); Karabag, 1958: 32 (faunistic catalogue); Karabag, 1962: 10 (remark); Çiplak et al., 1993: 11, 18 (distribution map, checklist,); Otte, 1997: 125 (catalogue); Naskrecki \& Otte, 1999: (catalogue); Çiplak et al., 1999: 752 (checklist, distribution); Çiplak et al., 2002: 685 (checklist, distribution). Databanks: SysTax, OSF2.

Artvinia tschorochensis: Karabag, 1962: 10; Salman, 1978: 19 (distribution); Otte, 1997: 113 (catalogue); Naskrecki \& Otte, 1999 (catalogue); Çiplak et al., 1999: 753 (checklist, distribution); Çiplak et al., 2002: 686 (checklist, distribution). Databank: SYSTAX, OSF2.

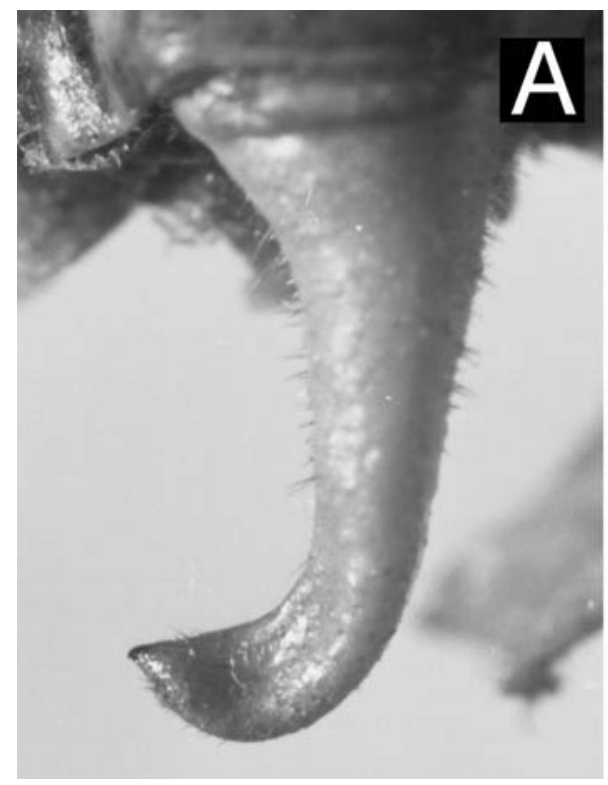

Remarks. The great similarity of $P$. rammei and P. tschorochensis has been known and discussed for a long time but few people have seen both species together. Miram (1938) noted in her description of $P$. ramme $i$ the similarity of this species to $P$. tschorochensis, but gave no diagnostic characters. Ramme (1951) examined only $P$. rammei and concluded from the description of $P$. tschorochensis that the shape of the cerci were different in these species. Bey-Bienko (1954) was obviously the first to examine specimens from both species. In his material (30, 4 ㅇ of $P$. rammei, $2 \hat{\sigma}$ of $P$. tschorochensis) he found mainly differences in coloration and the shape of the cerci. Karabag (1962) also did not see specimens of P. rammei, but in his study of $P$. tschorochensis he assumed it would be the same species. Studying the descriptions and examining our rich material, mainly of $P$. tschorochensis, we found no distinct differences between them. Coloration and the shape of the cerci (Fig. 6) are nearly identical. There are also no differences in the width of fastigium and structure of the last tergite. P. rammei Miram, 1938 is therefore considered to be a synonym of $P$. tschorochensis Adelung, 1907.

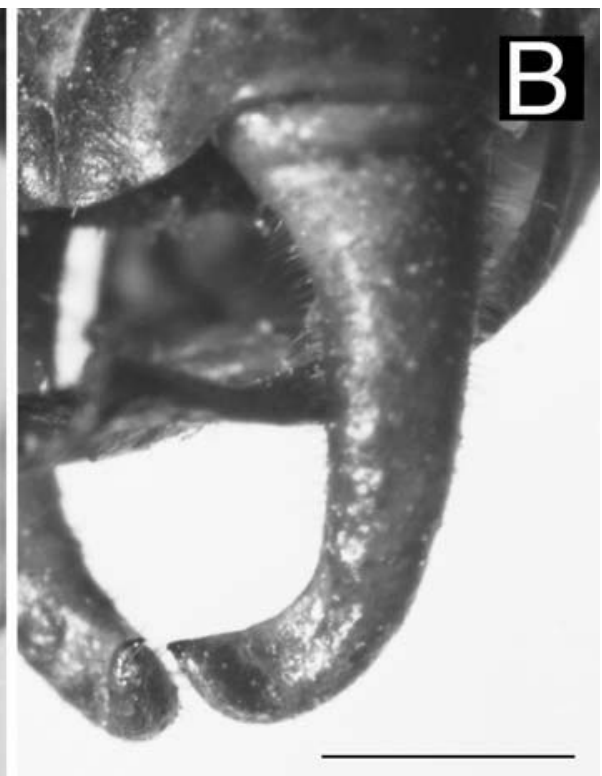

Fig. 6. Male cerci. A - Poecilimon tschorochensis (Yalnizcam pass, locus typicus, CH1866); B - P. tschorochensis (paratype P. rammei). Scale $1 \mathrm{~mm}$. 

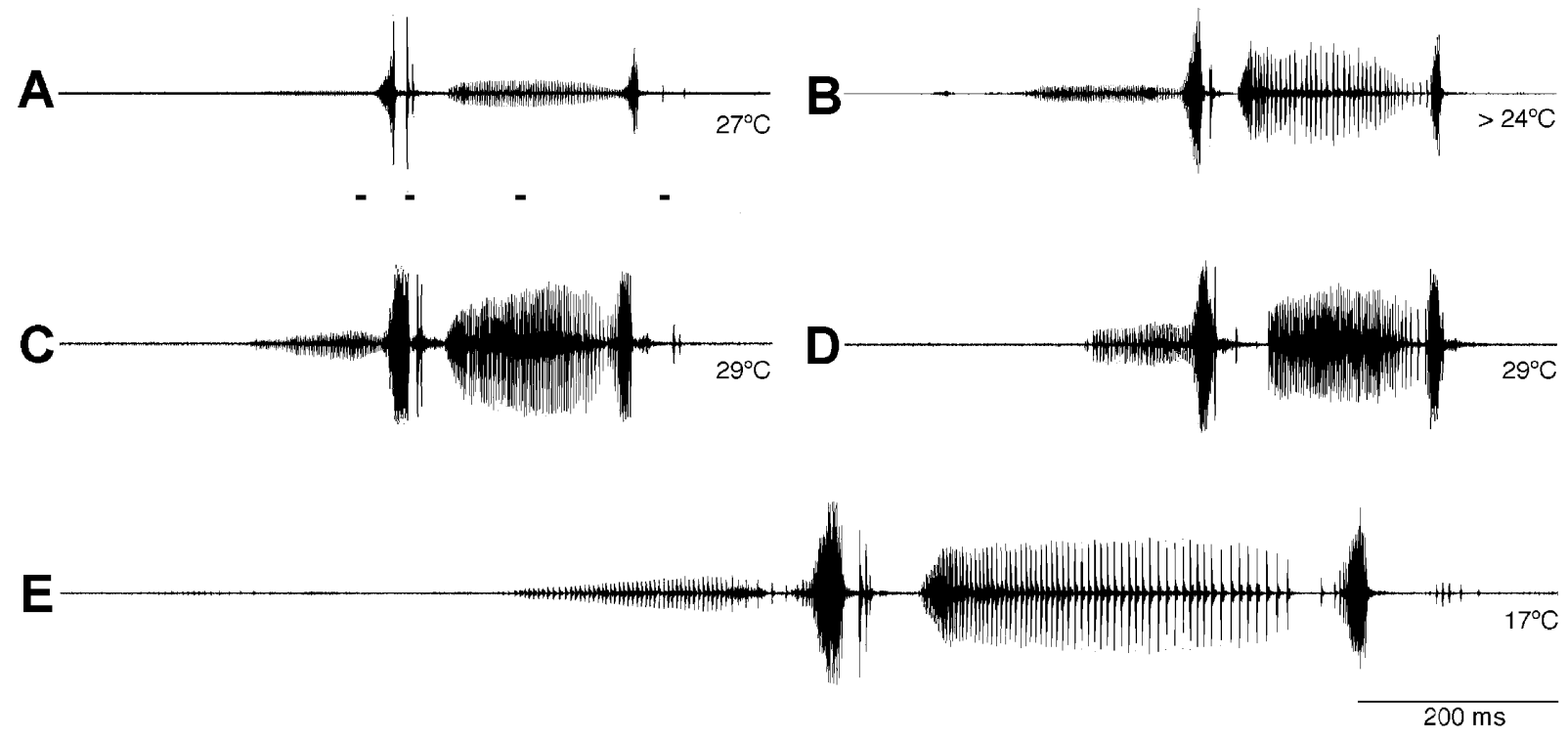

Fig. 7. Oscillograms of the calling song of $P$. tschorochensis from different localities and at different temperatures; A, B, E - Yalnizcam pass; C - Bilbilan yaylasi; D - Kutul yaylasi. Frequency range of recording A: 1-100 kHz, B-E: 1-20 kHz. Horizontal marks on recording A indicate the position of the spectra presented in Fig. 8.

Material examined. Turkey: Artvin: holotype (ZIN); 150 , 2 i Yalnizcam pass, eastern slope, 2200-2400 m a.s.1., 10.-11.viii.1983, leg. K.-G. Heller (CH) (song heard in many places on both sides of the pass, in the northern end down to about $1700 \mathrm{~m}) ; 150,13 \%$ Yalnizcam pass, 9.viii.1987, leg. K. Reinhold $(\mathrm{CH}) ; 10$, Gurdzhany (determined to be situated at $\left.41^{\circ} 21^{\prime} 40^{\prime \prime} \mathrm{N}, 41^{\circ} 25^{\prime} 37^{\prime \prime} \mathrm{E}\right)$, two labels, one with Cyrillic letters, one with Latin letters: Guzhang, 28.v.1910, leg. Nesterov (hand written, possibly by Miram or Ramme), paratype $P$. rammei

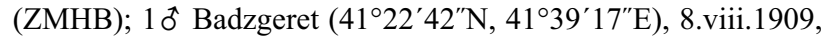
leg. A. Satunin (ZIN); 20, 2 ㅇ, Kutul, 2100 m, 2.viii.1972, leg. A. Koçak (HUZOM); 150, 6 ㅇ, Ardanuç, Kutul Yaylasi, Orman kenari, $41^{\circ} 04.373 \mathrm{~N}, 42^{\circ} 13.245 \mathrm{E}, 2230 \mathrm{~m}, 26 . v i i .2002$, leg. $\mathrm{H}$. Sevgili (HUZOM); $8 \hat{0}, 1$ 우 (on Urtica sp.), Bilbilan yaylasi, $41^{\circ} 03.567$ N, $42^{\circ} 16.688$ E, 2485 m, 26.vii.2002, leg. H. Sevgili (HUZOM); 70ิ, 1 ㅇ, Yalnizçam daglari, Kutul geçidi, $2150 \mathrm{~m}$, 2.viii.1973, leg. S. Salman (HUZOM); 10 , 2 으, Savsat, Meseli Köyü Yaylasi, $2000 \mathrm{~m}, 41^{\circ} 31^{\prime} \mathrm{N} 42^{\circ} 53^{\prime} \mathrm{E}$, 18.viii.2005, leg. H. Sevgili (one of these females collected by S.S. Caglar; HUZOM); Ardahan: $2 \%$, Yalnizçam, Bilbilan yaylasi, $2400 \mathrm{~m}$, 20.viii.1974, 1 ㅇ, 15.viii.1974, 10 , 1 우 , the same locality, 2500 m, 15.ix.1973, leg. S. Salman (HUZOM) (area on the border between Artvin and Ardahan);

Previous records. Turkey: Artvin: type locality (Adelung, 1907); Badzgeret (Bey-Bienko, 1954); Gurdzhany (= Gurdjan (?) in Karabag, 1958), type locality of P. rammei (Miram, 1938); Kutul yaylasi, ca. $2500 \mathrm{~m}$ a.s.1. (Karabag, 1958) (1 0 in ZMHU, SysTax); Kutul gecidi (Salman, 1978); Ardahan: Bilbilan Yaylasi (Salman, 1978).

Bioacoustics. The calling song consists of pairs of syllables separated by intervals of several seconds (Fig. 2; mean/median $10 / 8.5 \mathrm{~s}, \mathrm{n}=25$ intervals $/ 12$ males, $\mathrm{T}=$ $29^{\circ} \mathrm{C}$ ). Each pair has a relatively complicated structure in time and frequency domain. After the first opening movement which is mostly but not always silent, the male closes the tegmina slowly at the beginning and quickly at the end. During the slow phase a series of faint impulses is produced (Fig. 7; due to the very low amplitude com- pared to the loud parts of the song they are difficult to recognise in Fig. 3). During the fast closing phase the sound becomes much louder and the previously separated impulses fuse into one or a few irregular pulses. At the beginning of the opening movement of the second syllable two to three, rarely one short, but quite loud pulses are produced (Fig. 3). The remaining opening movement is silent, but immediately at the beginning of the closing movement a long series of impulses can be heard (mean 84 impulses, range $50-120, \mathrm{n}=49$ syllables/17 males). This series is again produced during a slow closing movement, which is followed by a fast phase from which one or a few pulses result. After an interval of 40-80 ms (at T $=29^{\circ} \mathrm{C}$ ) often, but not always one or two afterclicks are produced. In recordings taken at night mostly a longer series of afterclicks ( $2-5$ afterclicks; $n=10$ syllables, $\geq 2$ males; $\mathrm{T}=17^{\circ} \mathrm{C}$ ) could be heard. The duration of the first closing hemisyllable was $136 \pm 27 \mathrm{~ms}$, that of the second $184 \pm 15 \mathrm{~ms}$ and that of the whole second movement cycle $225 \pm 14 \mathrm{~ms}(\mathrm{n}=31$ syllables, $1-3$ from 12 males; $\mathrm{T}=29^{\circ} \mathrm{C}$ ). At lower temperatures the duration of all parts can, of course, be much longer (Fig. 7).

In the analysis of the frequency composition (Fig. 8; for the position of the spectra within the song see Fig. 7) it can be seen that during the impulse series of the first and second syllable audible components dominate, mainly over a quite narrow frequency band of between $5-10 \mathrm{kHz}$ (mean of frequency maximum: $6.7 \pm 0.8 \mathrm{kHz}, 10 \mathrm{~dB}$ below maximum: $5.6-8.1 \mathrm{kHz} ; \mathrm{n}=18$ males). During the fast closing movements and in the opening hemisyllable, however, much louder, broadbanded ultrasound components were registered together with low frequency components. Due to these ultrasound components, the amplitude of these parts is strongly underestimated in recordings made using audio tape recorders (compare Fig. 


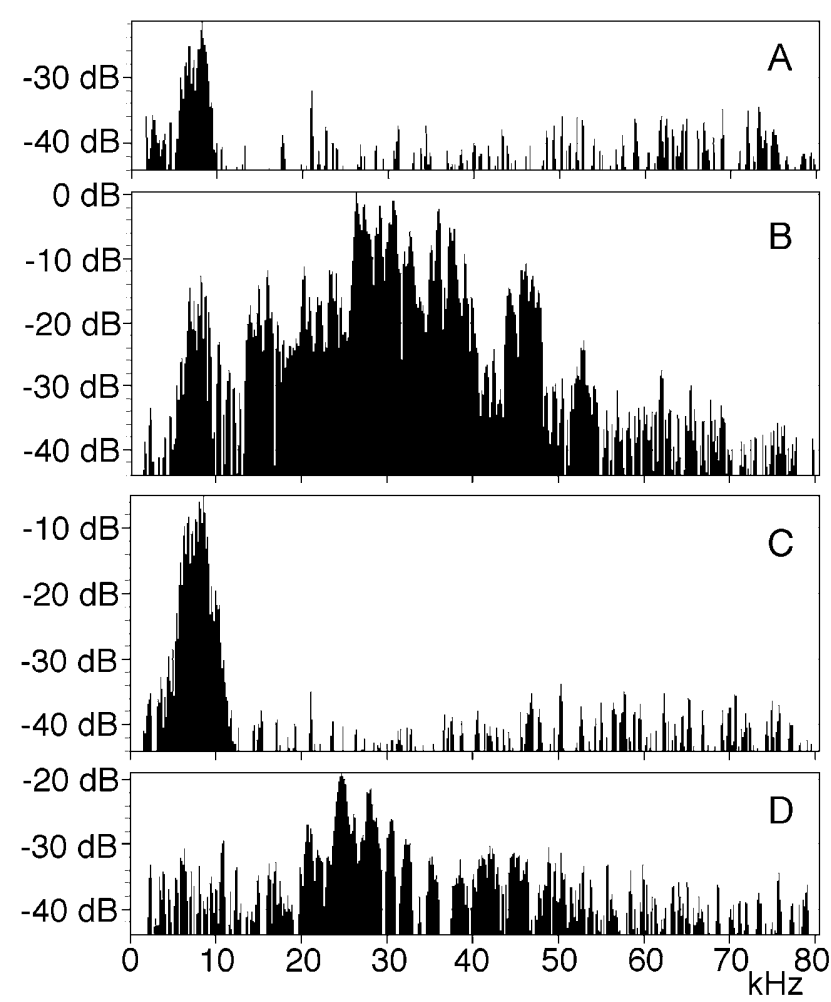

Fig. 8. Spectral composition of the calling song of P. tschorochensis (see Fig 7A for sequential positions of A-D).

3 and the different recordings in Fig. 7). In the afterclick mainly high frequency components were observed.

The occurrence of the different frequencies may be explained by the assumption of at least two resonators within the tegmina, which are activated differently. This hypothesis is supported by an examination of the stridulatory file, which is made up of two parts.

The stridulatory file of $P$. tschorochensis has a quite unusual shape, not observed in any other tettigoniid (Figs $9,10)$. The distal, about $2.5 \mathrm{~mm}$ long and straight part of the file bears about 110 small stridulatory teeth $(n=1$; several other tegmina similar). While closing the tegmina the scraper, which is situated on the edge of the right tegmen, has to run at first over this part of the file. Then the file bends sharply at a 50 degree angle towards the articulation of the wing. This proximal, again straight part bears 36 large teeth and is used for sound production just before closing the wings completely (Fig. 10). From the file structure and stridulatory movement it seems possible that during the first part of the closing hemisyllable the outer, heavily enlarged parts of the tegmen, which are bordered by the distal part of the file, vibrate. This accords well with the low frequency recorded. During the final fast closing movement more proximal and smaller areas of the tegmina may vibrate producing higher frequencies. The higher sound amplitude of this part of the syllable might be explained by the increased muscle power near the articulation. The pulses of the opening hemisyllable and the faint afterclicks may also be produced by stridulation using this part of the file.

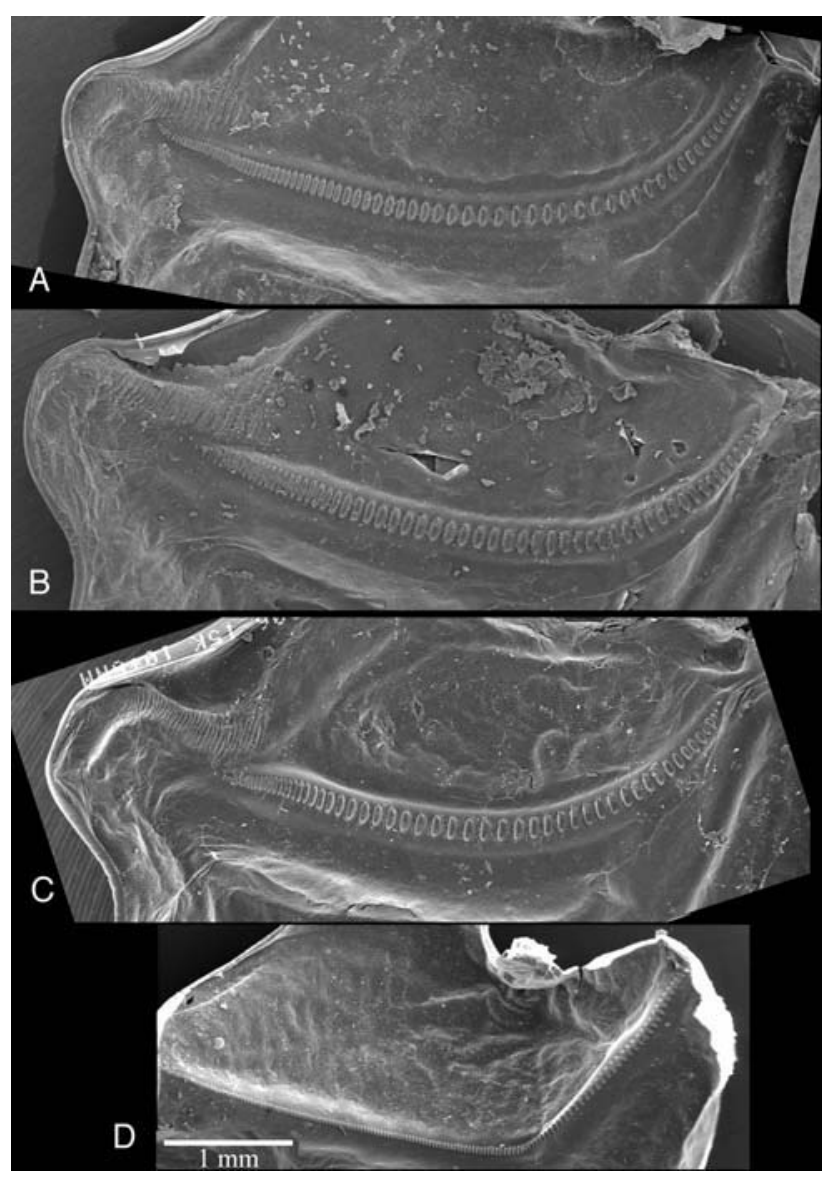

Fig. 9. Stridulatory file on underside of left tegmen of males, oriented so the tegmen articulation is on the right. A - Poecilimon heroicus, B $-P$. cf. heroicus, $\mathrm{C}-P$. bifenestratus, D P. tschorochensis.

The female tegmina overlap dorsally and the right one bears many stridulatory pegs on its dorsal surface as is typical for acoustically responding phaneropterids. The prothoracic spiracles of males and females are as large as those, for example, in P. laevissimus (Stumpner \& Heller, 1992).

\section{Remarks on behaviour and ecology}

During our short visits we did not notice acoustical duetting between males and females. Accidentally, however, we did observe parts of the courtship behaviour. After physical contact between male and female, the male elevated its huge tegmina and offered the female access to his dorsal glands (Fig. 1C). Initially the female was very interested in the glands (Fig. 1D), however, after some time she lost interest and left without mating. Dorsal glands of very different sizes are probably present in most or all species of Poecilimon and related genera, like Isophya (Engelhardt, 1915). In most species they are exposed and easily accessible for a female after she has mounted the male. Elevation of the tegmina was not observed in any short winged phaneropterid species, but is reported for long-winged species of that family (e.g. Scudderia furcata; own observations $\mathrm{KGH}$ ) and tree crickets (e.g., Brown, 1999). Remarkably, in the females 


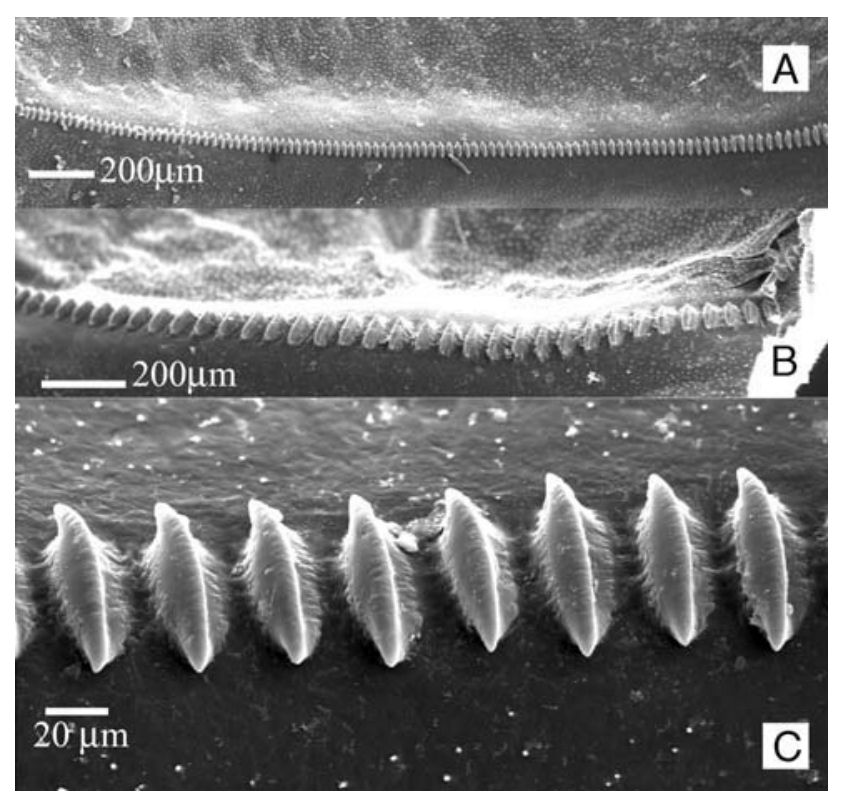

Fig. 10. Details of the male stridulatory file of P. tschorochensis ( $\mathrm{A}$ - distal part, $\mathrm{B}$ - proximal part, $\mathrm{C}$ - central part).

the first tergites are pale like the huge tegmina of the males (Fig. 1C). Some females, however, were completely green (except for reddish brown markings on the pronotum).

$P$. tschorochensis was found together with the phaneropterids Poecilimon similis richteri Ramme, 1933, Isophya zernovi Miram, 1938 and Isophya schneideri Brunner von Wattenwyl, 1878 and the tettigoniids Psorodonotus specularis (Fischer-Waldheim, 1846) and Parapholidoptera distincta (Uvarov, 1921). In Bilbilan, Yalnizcam Mts, they were mainly found on Urtica sp.

\section{DISCUSSION}

\section{Phylogeny}

The assumption of a close relationship between the four species mentioned above is based mainly on the unusual shape of the pronotum. It is also supported by their circum-Caucasian distribution. Within the group, Poecilimon tschorochensis does not show any synapomorphies with the other species and has to be considered as its most basal member. The other three species possess cerci, which have at least two teeth at their tip (Fig. 5), whereas $P$. tschorochensis shows the ancestral cercal shape, ending in one simple tooth (Fig. 6). Among these three species, the parapatric $P$. heroicus and $P$. bifenestratus share a complex of characters, all associated with non acoustical females. The tegmina of the females are small and do not overlap dorsally, and the auditory spiracles are strongly reduced in size. The systematic relationships can thus described as ( $P$. tschorochensis ( $P$. tricuspis (P. heroicus, $P$. bifenestratus))).

The origin of the group may therefore be north eastern Turkey (Caucasian part), from where it spread northwards to the Caucasus. Probably $P$. heroicus occupied the steppes of the foothills in the north of the Caucasus after the last ice age.

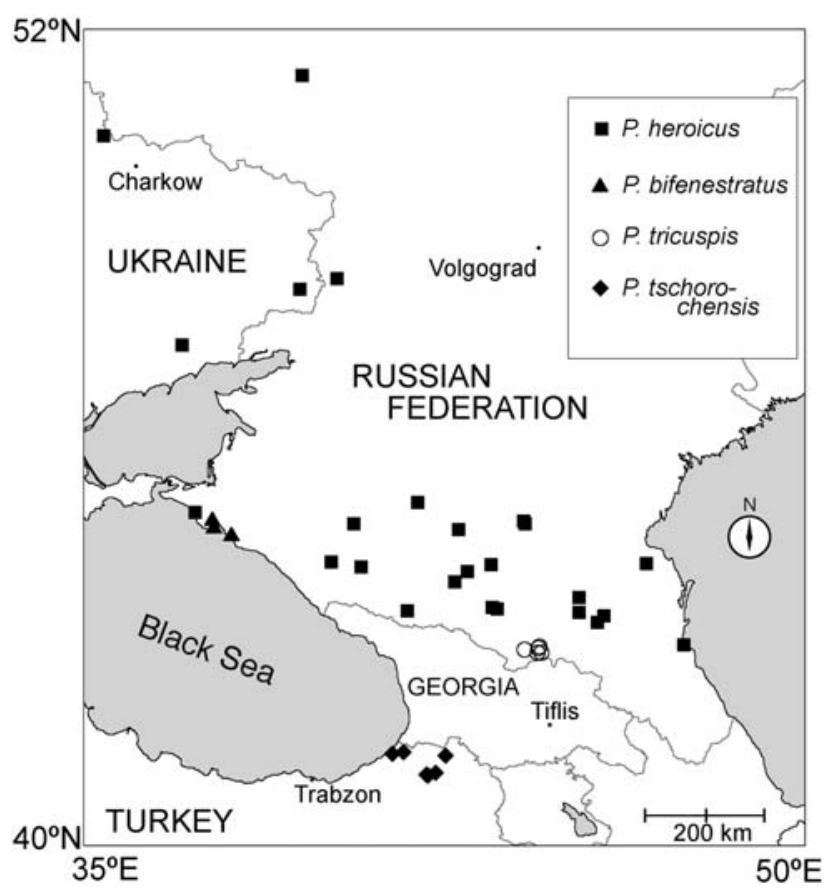

Fig. 11. Distribution map.

\section{Bioacoustics}

The most unusual character of the song of the species studied is its spectral composition, especially that of $P$. tschorochensis, which has the lowest peak frequency of all Poecilimon species, when the maxima of sound spectra are compared (Fig. 12). In the genus Poecilimon, the frequency maximum is negatively correlated with body size, but $P$. tschorochensis has neither a wider head or longer hind femora than other Poecilimon species. Regarding the huge size of its tegmina, however, the low frequency of song is not unexpected. $P$. heroicus and $P$. bifenestratus also have very low peak frequencies (Fig. 12). Both species are distinctly larger than P. tschorochensis but the deviation in the frequency expected due to their size is much smaller. However, the results indicate that a low frequency is a basal feature of the group, probably linked with the posterior widening of the pronotum and the enlargement of tegmina.

There are two advantages of low frequencies. First, sound signals with low frequencies have generally a larger range than those with high frequencies, a well known phenomenon in bioacoustics (for tettigoniids see Zhantiev, 1981; Römer \& Lewald, 1992). High frequencies, for example, are strongly attenuated in dense vegetation. Properties of the habitat of these Poecilimon species possibly favour the use of long sound wave lengths (low frequencies). This idea is supported by finding in the background of some field recordings of $P$. tschorochensis the song of Psorodonotus specularis, which has a similar spectral composition. Psorodonotus are large bushcrickets typically found near to the ground in moist habitats. $P$. bifenestratus sings on the ground or not very high up in vegetation, $P$. heroicus and $P$. tricuspis occur in grassland with great plant diversity, but typically not very 

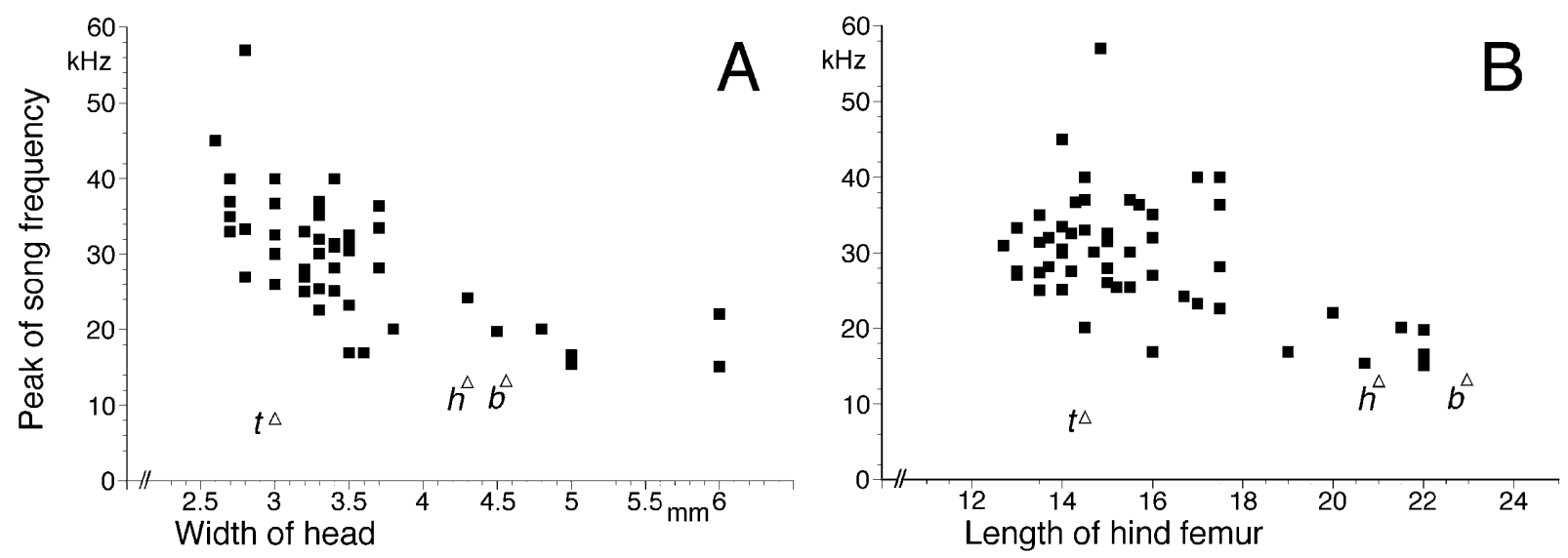

Fig. 12. Peak frequency of calling song relative to the width of head (A) and length of hind femur (B) in the genus Poecilimon; $b-$ $P$. bifenestratus, $h-P$. heroicus and $t-P$. tschorochensis; other species: P. affinis, ampliatus, anatolicus, angulatus, antalyaensis, artedentatus, bilgeri, bosphoricus, brunneri, chopardi, cretensis, deplanatus, ebneri, elegans, erimanthos, fussii, gracilis, hamatus, macedonicus, marmaraensis, mytilenensis, nobilis, obesus, orbelicus, ornatus, paros, pergamicus, pindos, propinquus, sanctipauli, schmidtii, scythicus, similis, thessalicus, thoracicus, tuncayi, turcicus, ukrainicus, unispinosus, v. veluchianus, v. minor, werneri, zimmeri, zwicki; data from Heller, 1988 and unpubl.).

tall plants. However, P. tschorochensis is found higher up in vegetation than Psorodonotus and appears at least not to be strictly bound to moist conditions (own observations).

A second reason for the use of low frequencies may be sexual selection. In many studies females have been shown to prefer larger than average males. If females judge size on the basis of properties of acoustical signals, they should prefer signals of lower than average frequency, because these might indicate larger males. Although the results from the few experiments addressing this question are far from clear (see Gerhardt \& Huber, 2002), the hypothesis may hold in some cases. The huge size of the tegmina in P. tschorochensis may be a consequence of a runaway process - a kind of acoustical peacock tail (Andersson, 1994).

Another interesting character change is the loss of an acoustical response by females within the $P$. heroicusgroup. The combination of characters related to this loss is known also in Poecilimon species of other groups (e.g., P. propinquus-group (Lehmann, 1998), P. ampliatusgroup (Heller \& Lehmann, 2004), which also have mute females. The $P$. heroicus-group, however, is the first group, where within a group this change in acoustic communication system can be traced. In both the above mentioned groups the females of all species have strongly reduced tegmina, too small to produce sounds. However, the systematic relations of the groups to each other as well as to acoustical responding species are unknown.

In all species similar changes are observed in the acoustical behaviour and hearing organs. P. tschorochensis with acoustical females produces echemes (combination of two syllables) at intervals of about $10 \mathrm{~s}$, whereas $P$. heroicus and $P$. bifenestratus produce long sequences of syllables at intervals of only about one second. Intervals of about the same difference in duration were recorded for Poecilimon species with acoustically responding and mute females, respectively (Heller \& Helversen, 1993), and this corresponds to the different functions of the song. In $P$. tschorochensis and similar species, the male song has to elicit an acoustical response from females, which is used by the male for his approach, whereas in $P$. heroicus and other species with mute females the female has to walk to the male guided by his song. P. heroicus and $P$. bifenestratus also show a reduction in the acoustic spiracles as observed in other Poecilimon species with mute females (Stumpner \& Heller, 1992). In P. heroicus and $P$. bifenestratus this change is more easily understood than in the smaller species, because the reduction in size of the prothoracic spiracle does not significantly decrease the auditory sensitivity at low frequencies (below about $10 \mathrm{kHz}$ ) (Stumpner \& Heller, 1992). In terms of the frequency of the male song, a reduction in the size of the spiracles might also be expected in $P$. tschorochensis. However, the female response includes ultrasonic components judging by the size of her tegmina (similar to the situation in Ancistrura nigrovittata (Dobler et al., 1994; Stumpner, 2002). Decoupling the size of male's and female's spiracles is less likely to occur during evolution than equally sized spiracles in both sexes.

For a deeper understanding of the evolution of this communication system more data on the response of females and the acoustic behaviour of $P$. tricuspis are urgently needed. A detailed study of all species of the group may uncover the reasons for the existence of two different acoustic communication systems in bushcrickets.

ACKNOWLEDGEMENTS. We are grateful to M. Volleth for some of the $P$. tschorochensis recordings, and to $\mathrm{O}$. von Helversen for organizing the excursion to Turkey in 1983. Our thanks go also to M. Chernyakhovsky (MSPU, Moscow), M. Ohl and I. Dorandt (both ZMHB, Berlin) for their kind help in working with the collections of Orthoptera at MSPU and ZMHB respectively, A. Liana for informations about the types of $P$. heroicus, S. Salman (Gazi University, Ankara) for collecting some specimens, A. Öner (Turkish Petrolium Corporation, 
Research Center, Ankara) and A. Demirsoy (Hacettepe University, Ankara) for scanning electron microscopy, and F. Willemse for helpful comments on earlier versions of the manuscript. This work is partially supported by grant 00-0448189 from the Russian Foundation for Basic Research.

\section{REFERENCES}

Adelung N.V. 1907: Beitrag zur Kenntnis der Orthopterenfauna Transkaukasiens. Trudy Russk. Entomol. Obshch. 38: 32-82.

Andersson M. 1994: Sexual Selection. Princeton University Press, $624 \mathrm{pp}$.

Bey-Bienko G.YA. 1930: Studies on the Tettigoniidae of the North Caucasian region and adjacent localities. Caucas. Plant. Prot. Stat. 5: 49-64 [in Russian, English abstr.].

Bey-Bienko G.YA. 1932: Orthoptera. In Shtakelberg A.A. (ed.): List of Insect Pests of U.S.S.R. and Adjacent Countries. Trudy po Zashchite Rastenii, Entomologiya 5. pp. 5-33, 222-227.

Bey-Bienko G.YA. 1933: Records and descriptions of some Orthoptera from U.S.S.R. Bol. R. Soc. Esp. Hist. Nat. 33: 317-341.

Bey-Bienko G.YA. 1954: Orthoptera Vol. II, Sect. 2. Bushcrickets. Subfam. Leaf Bush-crickets (Phaneropterinae). In: Fauna U.S.S.R. (NS) 59. Inst. Zool. Acad. Sci. URSS, pp. 1-385 [English translation: 1965, Israel Program for Scientific Translations, Jerusalem].

Brown W.D. 1999: Mate choice in tree crickets and their kin. Annu. Rev. Entomol. 44: 371-396.

Chernyakhovsky M.E. 1994: Fauna and ecological distribution of Orthoptera in North Ossetia. Zool. Zh. 73: 53-60.

ÇIIPLAK B. 2004: Biogeography of Anatolia: the marker group Orthoptera. Mem. Soc. Entomol. Ital. 82[2003]: 357-372.

Çiplak B., Demirsoy A. \& Bozcuk N. 1993: Distribution of Orthoptera in relation to the Anatolian diagonal. Articulata 8: $1-20$.

ÇiplaK B., Yalim B. \& Demirsoy A. 1999: Orthoptera Fauna of Turkey. In Demirsoy A. (ed.): General Zoogeography and Zoogeography of Turkey: Animal Zoogeography. Meteksan, Ankara, pp. 748-770 [in Turkish].

Çiplak B., Yalim B., Demirsoy A. \& Sevgili H. 2002: Orthoptera Fauna of Turkey. In Demirsoy A. (ed.): General Zoogeography and Zoogeography of Turkey: Animal Zoogeography. Meteksan, Ankara, pp. 681-707 [in Turkish].

Dobler S., Stumpner A. \& Heller K.-G. 1994: Sex-specific spectral tuning for the partner's song in the duetting bushcricket Ancistrura nigrovittata (Orthoptera: Phaneropteridae). J. Comp. Physiol. (A) 175: 303-310.

ENGELHARDT V. 1915: On the structure of the alluring gland of Isophya acuminata Br. W. Bull. Soc. Entomol. Moscow 1: 58-63 [in Russian].

FRIVALDSZKY J. 1867: A magyarországi egyenesröpüek magánrajza. [Monographia Orthopterorum Hungariae.] E. Gusztavnal, Pest, 201 pp. [in Hungarian].

Gerhardt H.C. \& Huber F. 2002: Acoustic Communication in Insects and Anurans. University of Chicago Press, $531 \mathrm{pp.}$

Harz K. 1969: Die Orthopteren Europas 1. Series Entomologica 5. Dr. W. Junk, The Hague, $\mathrm{xx}+749 \mathrm{pp}$.

Heller K.-G. 1984: Zur Bioakustik und Phylogenie der Gattung Poecilimon (Orthoptera, Tettigoniidae, Phaneropterinae). Zool. Jb. Syst. 111: 69-117.

Heller K.-G. 1988: Bioakustik der europäischen Laubheuschrecken. Josef Margraf, Weikersheim, $358 \mathrm{pp}$.

HELLER K.-G. 1990: Evolution of song pattern in east Mediterranean Phaneropterinae: Constraints by the communication system. In Bailey W.J. \& Rentz D.C.F. (eds): The Tettigonii- dae: Biology, Systematics and Evolution. Crawford House Press, Bathurst \& Springer, Berlin, pp. 130-151.

Heller K.-G. 2004: Poecilimon martinae sp. $\mathrm{n}$ and P. inflatus Brunner von Wattenwyl, 1891 (Orthoptera, Tettigonioidea, Phaneropteridae), two bush-cricket species endemic to southwest Anatolia: morphology, bioacoustics and systematics. Articulata 19: 1-17.

Heller K.-G. \& Helversen D.V. 1993: Calling behavior in bushcrickets of the genus Poecilimon with differing communication systems (Orthoptera: Tettigonioidea: Phaneropteridae). J. Insect Behav. 6: 361-377.

Heller K.-G. \& Lehmann A. 2004: Taxonomic revision of the European species of the Poecilimon ampliatus-group (Orthoptera: Tettigonioidea: Phaneropteridae). Mem. Soc. Entomol. Ital. 82[2003]: 403-421.

Heller K.-G. \& Sevgili H. 2005: Systematics and bioacoustics of the Poecilimon sanctipauli-group (Orthoptera: Tettigonioidea: Phaneropteridae). Eur. J. Entomol. 102: 265-277.

Heller K.-G., Korsunovskaya O., Ragge D.R., Vedenina V., Willemse F., Zhantiev R.D. \& Frantsevich L. 1998: Checklist of European Orthoptera. Articulata 7, Beiheft: 1-61.

Heller K.-G., Willemse F. \& Sevgili H. 2005: Poecilimon mytilenensis Werner, a polytypic phaneropterid bushcricket from the Aegean islands (Orthoptera, Tettigonioidea), differing in male mating structures. J. Orthopt. Res. 13[2004]: 221-230.

Helversen O.V. \& Elsner N. 1977: The stridulatory movements of acridid grasshoppers recorded with an opto-electronic device. J. Comp. Physiol. 122: 53-64.

Karabag T. 1956: The genus Phonochorion Uvarov (Orthoptera: Tettigoniidae). Proc. R. Entomol. Soc. Lond. (B) 25: 49-52.

Karabag T. 1958: The Orthoptera Fauna of Turkey. T.C. Ankara Univ. Fen Fakult. Yayinlari, Istanbul, xiii + 198 pp.

Karabag T. 1962: Some new and little known Phaneropterinae (Orthoptera: Tettigoniidae) from Turkey. Proc. R. Entomol. Soc. Lond. (B) 31: 4-10.

KIRBY W.F. 1906: A Synonymic Catalogue of Orthoptera. Vol. II. Orthoptera Saltatoria. Part I. (Achetidae et Phasgonuridae). The Trustees of the British Museum, London, pp. i-viii, 1-562, 1-25.

Lehmann A. 1998: Speciation, Acoustic Communication and Sexual Selection in Greek Bush-Crickets of the Poecilimon propinquus Group (Tettigonioidea, Phaneropteridae). Dissertation, University Erlangen-Nürnberg, 134 pp. [in German].

Medvedev S.I. 1950: Preliminary note about study of entomofauna of Provalskaya steppe in Viroshilovgrad area. Trudy Inst. Biol. Kharkov. Univ. 14-15: 89-109 [in Russian].

Miram E. 1926: Beitrag zur Orthopteren-Fauna Ciskaukasiens. Russk. Entomol. Obozr. 20: 275-279.

Miram E. 1929: Beitrag zur Kenntnis der paläarktischen Orthopteren. C. R. Acad. Sci. URSS 1929: 115-118.

Miram E. 1938: New species of the genera Poecilimon Fisch.-W. and Isophya Br.W. (subf. Phaneropterinae fam. Tettigoniodea - long-horned grasshoppers) of the fauna of the USSR. Zool. Zh. 17: 348-372 [in Russian, English abstr.].

MistshenKo L.L. 1972: Orthoptera. In: Insects and Mites - Pest of Agriculture. Nauka, Leningrad, pp. 16-115 [in Russian].

MUSHINSKY A.I. 1930: Materials to the knowledge of harmful katydids in Northern Caucasus. Izv. Sev.-Kavkaz. Sta. Zastsh. Rast. 5: 65-77 [in Russian].

Naskrecki P. \& OtTe D. 1999: An Illustrated Catalog of Orthoptera Vol. I. Tettigonioidea (Katydids or Bush-Crickets). CD-Rom published by the Orthopterists' Society at the Academy of Natural Sciences of Philadelphia. 
Oтте D. 1997: Orthoptera Species File 7. Tettigonioidea. Orthopterists' Society at the Academy of Natural Sciences of Philadelphia, Philadelphia, 373 pp.

ÖZBEG H. \& AsLan I. 1996: A study on the grasshopper species, Poecilimon tricuspis Miram 1926 (Orthoptera, Tettigoniidae) making outbreaks in some villages of Uzundere in Erzurum. Türkiye 3. Entomoloji Kongresi, Ankara, pp. 44-51 [in Turkish; English abstr.].

Pylnov E. 1909: Contributions à l' étude de la faune des Orthoptères des cosaques du Don. Russk. Entomol. Obozr. 9: 14-23 [in Russian].

Ramme W. 1933: Revision der Phaneropterinen-Gattung Poecilimon Fisch. (Orth. Tettigon.). Mitt. Zool. Mus. Berlin 19: 497-575, pls 6-12.

Ramme W. 1951: Zur Systematik, Faunistik und Biologie der Orthopteren von Südost-Europa und Vorderasien. Mitt. Zool. Mus. Berlin 27: 1-432, pls 1-39.

RöMER H. \& LEWALd J. 1992: High-frequency sound transmission in natural habitats: implications for the evolution of insect acoustic communication. Behav. Ecol. Sociobiol. 29: 437-444.

Salman S. 1978: Orthoptera of the provinces Agri, Coruh, Kars. Atatürk Üniversitesi Yayinlari No. 490, Fen Fakültesi Yayinlari No. 82. Arastirma Serisi 54: 1-128 [in Turkish].

SeVGiLi H. 2001: A new bushcricket species and notes on some less known species of the genus Poecilimon Fischer, 1853 from Turkey (Orthoptera, Phaneropterinae). J. Orthopt. Res. 10: $15-24$.

Stolyarov M.V. 2005: New data on distribution and taxonomy of the Orthoptera from Caucasus 1. Stenopelmatoidea and Tettigonioidea. Proc. Russ. Entomol. Soc. 76: 62-71 [in Russian].

StShelKanovtzev J.P. 1910: Saltatorial Orthoptera of Caucasia. Trav. Lab. Cab. Zool. Univ. Varsovie 1909: 1-70 [in Russian].

Stshelkanovtzev J.P. 1911: Notes on Russian saltatorial Orthoptera. Trav. Lab. Cab. Zool. Univ. Varsovie 1910: 153-180 [in Russian].

Stshelkanovtzev J.P. 1921: Contributions à la faune des Orthoptères (Orthoptera saltatoria) de la Russie. Entomol. Oboz. 17[1917]: 135-138 [in Russian].

StUmpNer A. 2002: A species-specific frequency filter through specific inhibition, not specific excitation. J. Comp. Physiol. (A) 188: 239-248.
Stumpner A. \& Heller K.-G. 1992: Morphological and physiological differences of the auditory system in three related bushcrickets (Orthoptera, Phaneropteridae, Poecilimon). Physiol. Entomol. 17: 73-80.

TARBINSKY S.P. 1948: Order Orthoptera (Saltatoria). In Tarbinsky S.P. \& Plavilshikov N.N. (eds): Keys to Insects of European Part of USSR. Selkhozgiz, Moscow, Leningrad, pp. 104-127 [in Russian].

Uvarov B.P. 1915: A note on the orthopteran fauna of Stavropol province. Izv. Kavkaz. Muz. 9: 77-110 [in Russian].

Uvarov B.P. 1928: Blattodea, Mantodea, Orthoptera, Phasmodea, Dermaptera. In Filip'ev N.N. (ed.). Insect Key. Moscow, pp. 68-72, 74-114, 120-122.

WALker T.J., Forrest T.G. \& SpoONer J.D. 2003: The rotundifolia complex of the genus Amblycorypha (Orthoptera: Tettigoniidae): Songs reveal new species. Ann. Entomol. Soc. Am. 96: 433-447.

WarchalowsKa-Sliwa E. 1998: Karyotype characteristics of katydid Orthopterans (Ensifera, Tettigoniidae), and remarks on their evolution at different taxonomic levels. Folia Biol. 46: 143-176.

WarchalowsKa-Sliwa E., Bugrov A.G. \& MaryansKaNADACHOWSKA A. 1995: Karyotypes of three species of the genera Poecilimon Fisch. and Isophya Br.-W. (Orthoptera, Tettigonioidea, Phaneropterinae) from the North Caucasus. Caryologia 48: 27-34.

Zhantiev R.D. 1981: Bioacoustics of Insects. Moscow University Press, Moscow, 256 pp. [in Russian].

Zhantiev R.D. \& Korsunovskaya O.S. 2005: Acoustic signals of the bush crickets of tribe Barbitistini (Orthoptera, Tettigoniidae, Phaneropterinae) from eastern Europe and Caucasus. I. Poecilimon Fisch., Isoimon B.-Bienko. Russ. Entomol. J. 14: 101-111.

\section{DATABANKS}

SysTax (a Database System for Systematics and Taxonomy): http://www.biologie.uni-ulm.de/systax/daten/index.html

OSF2 Orthoptera Species File online version 2.1: http://140.247.119.145/Orthoptera* (21/12/2005), former/ other version http://www.tettigonia.com (21/12/2005)

$\mathrm{FaEu}$ (Fauna Europaea) http://www.faunaeur.org

Received January 27, 2006; revised and accepted April 28, 2006 